\title{
A COMPREHENSIVE CORPUS-BASED STUDY OF THE USE OF EVALUATIVE ADJECTIVES IN PROMOTIONAL HOTEL WEBSITES ${ }^{1}$
}

\author{
Nuria Edo Marzá, Universitat Jaume I \\ Email: nedo@ang.uji.es
}

\begin{abstract}
The purpose of this paper is to analyse and, if necessary, qualify the high incidence of evaluative adjectives presumably to be expected in promotional hotel websites. Thus, the aim of the study is to understand the role they play in that genre, the way they work, their actual usage and possible classification, as well as the role they take in persuading the reader. This corpus-based study of evaluative adjectives was therefore grounded on the analysis of their syntactic behaviour, their recurrent collocational patterns and on drawing up of a proposed classification with which to better comprehend the entities and acts that best represent the domain. At the same time, it will also provide a clearer understanding of the way they are portrayed in the genre (hotel websites) and in the type of discourse being analysed (promotional).
\end{abstract}

Keywords: evaluative adjective, corpus-analysis, promotional hotel website, collocation.

Título en español: Estudio global basado en corpus del uso de los adjetivos evaluativos en los sitios web promocionales de hoteles.

Resumen: El propósito de este artículo es analizar y matizar, en caso de que fuera necesario, la alta incidencia de adjetivos evaluativos presumiblemente esperable en las páginas web promocionales de hoteles con el fin de entender su rol en dicho género, su funcionamiento, uso real y posible clasificación, así como el papel que juegan a la hora de persuadir al lector. Este estudio de corpus sobre adjetivos evaluativos ha estado pues basado en el análisis de su comportamiento sintáctico, sus patrones colocacionales recurrentes y en la elaboración de una propuesta de clasificación para la mejor comprensión de las entidades y actos más representativos del dominio, así como de la manera en que son retratados en el género estudiado (páginas web de hoteles) y en el tipo de discurso analizado (promocional).

Palabras clave: adjetivo evaluativo, análisis de corpus, página web promocional de hotel, colocación.

\section{THE TOURISM INDUSTRY ON THE WEB}

Nowadays, tourism can be considered an industry that is closely related to ICTs (Information and Communication Technologies), especially in view of the fact that its

Date of reception: 1 April 2011

Date of acceptance: 8 November 2011 
products and/or services are intangible goods that need reliable, up-to-date, abundant and detailed information for their promotion, as well as optimal commercialisation. Within the broader spectrum of tourism, the hospitality industry (which is the one we have focused on here) is no exception in this respect and takes advantage of the possibilities offered by the World Wide Web and makes widespread use of it, as can be seen by the millions of hotel websites to be found on the Internet.

As Pierini (2009: 95) accurately portrayed: "the tourism industry is a global enterprise that has captured the relevance of the Web as a new mass medium for contacting potential receivers all over the world and promoting tourist products both in domestic and international markets".

However, this is a relatively new phenomenon, as not so long ago the tourism industry relied on (or could only rely on) traditional brochures to promote its destinations and corresponding accommodation. Brochures, of course, have not disappeared but promotion through the web is becoming increasingly common because of its scope, immediacy, economy, speed and visual potential, among many other advantages.

Accordingly, it is a necessary sign of evolution that hoteliers take advantage of the great number of opportunities generated by Internet technology by establishing their own websites for online promotions and reservations. This study therefore focuses on the way language in general, and evaluative adjectives in particular, are used for promotional purposes on these hotel websites.

The basic purpose of hotel websites would be to persuade customers through promotion and to make the tourist book a room. Broadly speaking, as Maalej (1992) stated with respect to advertising in general, we would be talking about "a discourse type whose main protagonists are people with specific ideas in mind seeking to cause a larger group of potential participants to change their beliefs and buying habits, by creating in them 'the impulse to buy"'. The history of advertising has always been linked to the issue of persuasion, which consists in triggering changes in attitude (Severin and Tankard 1992) with the aim of causing action to take place. With this aim in mind, the kind of discourse that will be found in any promotional genre will be one that is deeply dependent on a language of finely engineered, assembled and purposeful messages in which evaluative adjectives with appealing messages can be expected to play a crucial role.

\section{PROMOTIONAL DISCOURSE ON HOTEL WEBSITES}

One interesting aspect when first analysing promotional discourse is the accuracy of the term "promotional". In this respect, Shaw (2006) introduces the concept of interestedness, which refers to the extent a recipient may recognise a genre as being used to persuade him/ her to do something in benefit of the producer. A company brochure is one of the examples this author mentions in order to illustrate interested genres, in which the producer intends to persuade the recipient to contribute to his/her own profits. Shaw (2006) describes the term promotional as rather ambiguous, but he agrees that promotional genres are genres whose main aim is to promote the producer's interests.

Hotel websites are an important tool for making reservations but, as Wong and Law (2005) stated: "hospitality researchers have rarely investigated the underlying reasons why

Odisea, $n^{\circ}$ 12, ISSN 1578-3820, 2011, 97-123 
travellers reserve rooms through a hotel website". From our experience as hotel website users, we hypothesise that the use made of adjectivation, and specifically evaluative adjectivation, on these websites is a way (that may be more or less accurate or faithful to reality) of attracting and persuading the potential client by "selling extraordinariness". Evaluative adjectives play a crucial role for tourists to be able to form an image of the suitability and convenience of booking a hotel. This portrayed "extraordinariness" would be constructed on the basis of a well-elaborated discourse emphasising positive traits and describing aspects, sometimes in an overwhelming manner, that prospective clients may find appealing and decisive for making a decision about accommodation. We thus set out from the hypothesis that these kinds of evaluative adjectives are very common on promotional hotel websites, as some rather "overloaded" samples of real discourse seem to indicate:

The rooms are decorated with elegant muted tones creating a modern twist entwined with the wonderful Victorian Architecture, giving way to a peaceful luxurious haven.

Nonetheless, the recipient is normally familiar with these kinds of genres and is therefore aware of the fact that they are not instances of purely objective impartial discourse, since they do not normally mention any weaknesses or shortcomings, leaving aside any negative aspects and exaggerating positive ones. Thus, this article tries to analyse how and to what extent the evaluation of interested genres is mostly (indeed I would say exclusively) positive and tends towards hyperbole. At the same time it also aims to examine the way evaluative adjectives participate in carrying out this super-positive portrayal.

Regarding the specific genre under analysis, hotel websites must be usable, functional, up-to-date, and show accurate and interesting information. This information may be presented in a number of ways which can be more or less appealing and thus have a stronger or lighter effect on what the hotelier purports through the web. Additionally, hotel websites tend to have a marked visual component, since websites in general could not be conceived without the fundamental role played by the images in them.

Nonetheless, when it comes to attracting visitors through a website the importance of language may be even more specific and informative than an image, and it is obviously more space-saving. As Majó and Galí (2002: 397) stated: "podemos definir la información turística como el conjunto de servicios que se ofrecen al turista con el objetivo de informarlo y orientarlo durante su estancia, o incluso, todas aquellas informaciones que le ayudarán a prepararlo de forma más precisa" [We can define tourist information as the group of services offered to the tourist with the aim of informing and orienting him/her during his/her stay or even all the information that will help him/her to prepare it in a more accurate way].

Nevertheless, although potential customers are aware of the conventions of promotional genres and of their tendency towards exaggeration, hoteliers know that almost anybody's inner cognitive processes would be more attracted by the noun groups "truly amazing views" or "absolutely extraordinary buffet" than by the plain use of the nouns "views" or "buffet".

It is also true, however, that promotional hotel websites should also try to avoid making their discourse sound too blatant. It must be kept in mind that when users enter a hotel website with the intention of (possibly) making a reservation, their main interest is to find out precise, objective data about the place they will stay in: is breakfast included? Is there any/free/wireless internet connection? Can I add an extra bed? That is to say, what could 
be considered a good hotel website should combine both objectively stated important information on factual data with more descriptive paragraphs that positively modulate or elaborate on the meanings of the acts and entities portrayed in order to persuade potential customers. Adjectives are the words in charge of condensing an evaluation of this kind into a single lexeme, as the following sections attempt to illustrate.

\section{A COMPREHENSIVE APPROACH TO ADJECTIVES: USE, CATEGORISATIONS AND IMPLICATIONS}

Traditionally, less attention has been paid to adjectives than to other parts of speech. However, adjectives are the largest open word class in English after nouns and verbs (Leech 1989) and, grammatically and semantically, they have the same degree of importance as the other content words in the linguistic code. This category thus plays a prominent part in the English language in general and particularly in specific types of discourse or genres, since it is the one responsible for classifying events or entities or describing their qualities. Even though they differ in the syntactic form that such modification can assume, all languages provide some means of modifying or elaborating the meanings of nouns (Fellbaum, Gross and Miller 1993). Adjectives are probably the most prototypical way to express the qualification of a noun, even when words originally pertaining to other syntactic categories can also function as adjectives, as is the case of the present and past participle of terms and also of nouns premodifying other nouns. Therefore, the importance of adjectives in language seems beyond any doubt.

As this paper tries to show, adjectives seem to play a paramount role both in argumentation and persuasion; when convincing, reasoning, narrating and telling, adjectives are always present, and thus have a strong interpersonal dimension. Adjectives can account for merely objective or more subjective features and as such they can reveal much of the speaker's/writer's attitude towards the textual content. Consequently, they are widely used in those instances of discourse aimed at persuading the reader that the topic being dealt with is of interest and that what is being put forward is valuable and worth seeing.

Given their importance, especially in certain types of discourse, it therefore comes as not surprise that efforts have also been made to categorise adjectives from different perspectives in an attempt to better understand their use, implications and functioning. The literature on adjective categorisation is vast and varied, since adjectives have been classified in a multiplicity of ways depending on the criteria adopted. There is a first, elementary distinction or classification based on prototypicality, according to which adjectives can be "central" and "peripheral"/“non-central" (Quirk et al. 1972: 234; Huddleston 1984: 299 ff.; Biber et al. 1999: 507-508, among others). Central adjectives (prototypical ones), show gradability, have comparative and superlative forms and have the ability to occur both attributively and predicatively, whereas those which do not fulfil these criteria are known as non-central or peripheral due to their not-so-marked prototypical character. However, as Fragaki (2009) conceded, this distinction is quite broad and presents certain shortcomings, such as the fact that peripheral adjectives only constitute a category in themselves because of their contrast with central adjectives and not because they share a number of common features that make it coherent to gather them under a single category. 
There are other more accurate (or at least more specific) categorisations of adjectives based on morphological, functional, syntactic, pragmatic or semantic criteria or even based on a combination of some of these. Yet, what seems clear from these classifications (shown below) is that most of them identify at least two common adjective categories - that of descriptive/qualitative and classifying adjectives.

Semantic categorisations may follow concrete or abstract semantic criteria. For example, Dixon's (1982) proposal is firmly based on semantic features of the different adjectives and distinguishes the following 10 categories: dimension, physical properties, colour, age, value, speed, human propensity, similarity, difficulty and qualification. Further possible semantic categorisations (see Table 1) are those of Lee (1994), with 24 semantic classes of adjectives, and Hundsnurscher and Splett's (1982) proposal, in which they enumerated 13 semantic types despite acknowledging some inconsistencies in their classification.

\begin{tabular}{|c|c|c|}
\hline Lee & & Hundsnurscher and Splett (1982) \\
\hline 1. & Adjectives of Possession & Perceptional \\
\hline 2. & Adjectives of Tendency & Spatial \\
\hline 3. & Adjectives of Possibility & Temporality-related \\
\hline 4. & Adjectives of Necessity & Spatio-temporal \\
\hline 5. & Stative Adjectives & Material-related \\
\hline 6. & Dimensional Adjectives & Body-related \\
\hline 7. & Adjectives of Privaticity & Mood-related \\
\hline 8. & Objective plus Temporal Combination & Spirit-related \\
\hline 9. & Objective plus Locative Combination & Behaviour-related \\
\hline 10. & Material Adjective & Social-related \\
\hline 11. & Quantitative Adjective & Quantity-related \\
\hline 12. & Spatial Adjective & Relational \\
\hline 13. & Temporal Adjective & General \\
\hline 14. & Adjective of Affiliation & \\
\hline 15. & Instrumental Adjective & \\
\hline 16. & Adjective of Counterpart & \\
\hline 17. & Actional Adjective & \\
\hline 18. & Reference Adjective & \\
\hline 19. & Causative Adjective & \\
\hline 20. & Equivalence Adjective & \\
\hline 21. & Gradable Adjective & \\
\hline 22. & Modal Adjective & \\
\hline 23. & Occurrence Adjective & \\
\hline 24. & Comparison Adjective & \\
\hline
\end{tabular}

Table 1. Lee's (1994) and Hundsnurscher and Splett's (1982) semantic categorisation of adjectives.

Bloomfield (1933), Teyssier (1968) and Ferris (1993) developed their respective categorisation of adjectives (see Table 2 ) following mainly syntactic criteria. As Fragaki (2009) pointed out, in these three categorisations (in which equivalent or near-equivalent 
terms are aligned) the so-called central adjectives are named using the terms "descriptive", "adjective" and "ascriptive", respectively:

\begin{tabular}{|l|l|l|}
\hline Bloomfield (1933) & Teyssier (1968) & Ferris (1993) \\
\hline limiting & identifying & \\
\hline descriptive & adjective & ascriptive \\
\hline & classifying & associatives \\
\hline & & sense-qualifiers \\
\hline & & separatives \\
\hline
\end{tabular}

Table 2. Syntactic categorisations of adjectives (Fragaki 2009).

A combination of semantic, syntactic and morphological criteria is used in the categorisations proposed by various authors and presented in Table 3 (Fragaki 2009):

\begin{tabular}{|c|c|c|c|c|c|c|}
\hline Warren (1984) & $\begin{array}{l}\text { Fellbaum } \\
\text { et al. } \\
(1993)\end{array}$ & $\begin{array}{l}\text { Raskin \& } \\
\text { Nirenburg } \\
\text { (1996) }\end{array}$ & $\begin{array}{c}\text { Raskin \& } \\
\text { Nirenburg } \\
\text { (1998) }\end{array}$ & $\begin{array}{l}\text { Boleda Torrent } \\
\text { \& Alonso i Ale- } \\
\text { many (2003) }\end{array}$ & $\begin{array}{l}\text { Boleda et } \\
\text { al. (2004) / } \\
\text { Boleda et } \\
\text { al. (2005) }\end{array}$ & $\begin{array}{c}\text { Bertoldi \& } \\
\text { Chishman } \\
\text { (2007) }\end{array}$ \\
\hline \multicolumn{7}{|l|}{$\begin{array}{l}\text { adjectives with } \\
\text { identifying } \\
\text { functions }\end{array}$} \\
\hline $\begin{array}{l}\text { adjectives with } \\
\text { descriptive } \\
\text { functions }\end{array}$ & descriptive & $\begin{array}{l}\text { property- } \\
\text { based } \\
\text { adjectival } \\
\text { modification }\end{array}$ & scalar & qualitative & basic & qualifying \\
\hline $\begin{array}{l}\text { adjectives with } \\
\text { classifying } \\
\text { functions }\end{array}$ & relational & \multirow{3}{*}{$\begin{array}{l}\text { non-property- } \\
\text { based } \\
\text { adjectival } \\
\text { modification } \\
\text {-attitudes } \\
\text {-temporal } \\
\text {-membership } \\
\text {-event-related } \\
\text {-relative } \\
\text { (denominal) }\end{array}$} & denominal & relational & object & classifying \\
\hline \multirow{4}{*}{$\begin{array}{l}\text { not basic } \\
\text { adjectives } \\
\text { - parts of } \\
\text { nominalisations } \\
\text {-verbal } \\
\text {-adverbial }\end{array}$} & $\begin{array}{l}\text { reference- } \\
\text { modifying }\end{array}$ & & & nonpredicative & & $\begin{array}{l}\text { remissive } \\
\text { intentional }\end{array}$ \\
\hline & & & deverbal & & event & valencial \\
\hline & & & & & & modal \\
\hline & colour & & & & & \\
\hline
\end{tabular}

Table 3. Adjective categorisations from a combination of semantic, syntactic and morphological criteria.

Another group which could be defined as functional is the one comprising Halliday (1985), Sinclair (1990), Bache and Davidsen-Nielsen (1997) and Biber et al.'s (1999) categorisations, the latter being based on corpora studies. Halliday (1985: 163) called 
premodifying adjectives "epithets" or "classifiers". Epithets indicate some quality and can be subdivided into "experiential" (when indicating some more or less objective quality of a subset of possible referents denoted by the head of the noun phrase) and "attitudinal" if they express the speaker's subjective attitude towards the referent, such as in the adjectives excellent, amazing or delightful. Classifiers, as their name indicates, would be those adjectives that indicate a particular subclass of the thing in question: wireless connection, gas heater and so forth. Therefore, the property alluded to by the epithet may be an objective property of the thing itself (experiential epithet) or an expression of the speaker's attitude towards it (attitudinal epithet).

Finally, Kerbrat-Orecchioni's (1980) classification relies on pragmatic criteria for the categorisation of adjectives and identifies two categories of adjectives with respect to their role: "objective" and "subjective". Within the subjective type, she includes emotional and evaluative adjectives, the latter including the non-axiological and axiological sub-types.

\begin{tabular}{llll}
\hline Objective & Subjective & & \\
\cline { 2 - 4 } & Emotional & Evaluative & \\
\cline { 2 - 4 } & & Non-axiological & Axiological \\
\hline Single/married & Happy & Abundant & Correct \\
Malelfemale & Pathetic & Hot & Nice \\
& Heartbreaking & Large & Good \\
\hline
\end{tabular}

Table 4. Kerbrat-Orecchioni’s (1980) classification of adjectives.

According to Kerbrat-Orecchioni (1980), evaluative non-axiological adjectives imply a qualitative or a quantitative evaluation of the modified noun and do not reflect any emotional compromise on the part of the speaker/writer, apart from having a gradual nature. Evaluative axiological adjectives are fully subjective and, according to Soler (2002), they provide a qualitative evaluation, adding either a positive or a negative judgement to the modified noun. In consequence, they reflect the speaker's/writer's favourable or unfavourable position with regard to the modified noun.

Kerbrat-Orecchioni (1980) suggested that an "interpretative jump" supported by the speaker's/writer's cultural and ideological competence will be needed when passing from the enumeration of the objective properties of a noun to its subjective evaluation. This concept is analysed in this paper from the perspective of evaluative adjectives used on hotel websites.

\subsection{Evaluative adjectives: their definition and scope in this study}

"Evaluation", as Hunston and Thompson (2000) stated, is a slippery and complex notion, which has received several different labels depending on the author: Martin (2000) and Martin and White (2005) preferred the term appraisal, Biber et al. (1999) and Conrad and Biber (2000) used the term stance, Barton (1993) employed evidentiality, whereas in Hyland's (2005) view attitude markers and some hedges can be considered evaluative markers. While evaluation can be achieved by a wide variety of linguistic means, a very 
important and frequent way of evaluating is through the use of evaluative adjectives. In the line of the aforementioned variation in the term "evaluation", adjectives with an evaluative role have also been assigned different nomenclatures including "evaluative" adjectives (Tucker 1997; Hunston \& Francis 2000: 188-191; Swales \& Burke 2003; Samson 2006), "subjective evaluative adjectives" (Kerbrat-Orecchioni 1980) or "attitudinal epithets" (Halliday 1985: 163-164), among others.

Throughout this study, we have used the term evaluation applied to adjectives in its broadest semantic sense, as understood by Hunston and Thompson (2000: 5): “[...] evaluation is the broad cover term for the expression of the speaker or writer's attitude or stance towards, viewpoint on, or feelings about the entities or propositions that he or she is talking about".

More specifically, the notion of evaluative adjective adopted here would be a combination of semantic, pragmatic and functional criteria. Hence, from now on in this paper, evaluative adjectives will refer to those adjectival instances combining the Hallidayan concept of "attitudinal epithets" (expressing the speaker's subjective attitude towards the referent) and Kerbrat-Orecchioni's notion of subjective adjectives (including emotional and non-axiological and axiological evaluative instances). Additionally, Swales and Burke's (2003) semantic classification of adjectives (see section 5.4) constitutes the third big approach that was adopted to shape the concept of evaluative adjective in this paper, which is reflected throughout the results section.

Following Hewings' (2004) terminology, two additional terms have also been used throughout this paper: an instance of an entity evaluated by an evaluative adjective has been referred to as an "adjectival evaluative act" to highlight that what is "done" is an act of evaluation, whereas the thing that is evaluated by an evaluative adjective in an adjectival evaluative act will be referred to as an "evaluated entity". Thus, in this paper, evaluative adjectives have been analysed with respect to significant evaluative acts or evaluated entities in promotional hotel websites.

We would also like to point out that evaluative adjectives are a large category that is often treated as part of the category of descriptive adjectives (Kamps \& Marx 2002; Hewings 2004), since "they are ascribed typical properties of this category such as gradability, ability to form comparatives and superlatives, antonymy, positive or negative semantic orientation" (Fragaki 2009: 9). However, they also have a different function, since descriptive adjectives attribute a property to the modified noun, whereas evaluative adjectives express the writer's evaluation.

Finally, as analysed in the sections that follow, evaluative adjectives, being one of the most prototypical and canonical exponents of evaluation (Swales and Burke 2003: 2), are especially significant in certain types of genres. In this paper, we have tried to provide empirical corpus data with the aim of corroborating, dismissing or qualifying the alleged or expected tendency of promotional genres towards making extensive (and sometimes rather hyperbolic) use of evaluative adjectives to accomplish their persuasive aims, since "language is never neutral and texts are never innocent" and "all selections are ideological" (Stubbs 1998: 371-372). 


\section{METHOD: CORPUS OF STUDY AND CORPUS EXPLOITATION TOOLS}

This study is based on the data retrieved and analysed from an English, untagged corpus of websites owned by both independent hotels and hotels belonging to chains from the United Kingdom and the USA. To favour the variation and representativeness of the 158 928-word (token) corpus of study, no more than one hotel per chain was used with the aim of preventing the idiosyncrasies of a single author from being reflected in the corpus. In the same way, only original, updated versions were included.

The corpus was analysed by means of the concordance software program WordSmith Tools 5.0 (WST), an integrated suite of programs that retrieves data on how words behave in texts and displays these data in different formats which focus on certain complementary aspects of linguistic study, apart from providing varied corpus counts and statistical data. WordSmith Tools has three main applications: Wordlist, Concord and KeyWords, of which the first two were used in this study. With Wordlist we obtained lists of words displayed in terms of their frequency in the corpus. From those lists, all the adjective types in the corpus were selected manually, with efforts then being made to identify every instance of evaluative adjectives from the 2000 top-frequency words in it. Next, Concord was used to analyse the concordances or KWIC (KeyWordInContext) lists of the evaluative adjectives under study (by means of the application Concordance) and the most frequent collocational patterns of these adjectives (by means of the application Collocates). The main aim of these analyses was to establish, both quantitatively and qualitatively, the syntactic behaviour of evaluative adjectives, then to identify recurring, significant collocations and finally to provide a mainly semantic/pragmatic classification of evaluative adjectives in order to better understand their use on promotional hotel websites. The following sections provide a more detailed account of these issues and the results obtained.

\section{RESULTS}

\subsection{Frequency lists: evaluative adjectives from the 2000 top-frequency lexical items in the corpus}

Given the purposes of this study, the first step was to generate a monolexical frequency list of words by means of the WordList application in WST. Since our corpus was not tagged for grammatical categories, types of a potential adjectival nature were manually selected from the 2000 top-frequency lexical units retrieved by Wordlist (once grammatical words had already been removed so as not to bias truly relevant corpus counts). According to the data analysed in previous studies of this sort (Hewings 2004; Fragaki 2009; Swales and Burke 2003; among others), in line with our own criteria and given the intended representativeness and variation of the corpus, we considered the 2000 top-frequency words to be a range that is wide enough to obtain representative data concerning the use of evaluative adjectives. This representativeness of the corpus (with respect to the subject field) seemed to be, at least preliminarily, corroborated by the kind of types obtained in the top 10 most frequent positions in the corpus: hotel (1241), facilities (951), breakfast (554), available (431), service (378), family (369), information (366), suite (346), guests (339) and services (339). 
Since our study is limited to adjectives in the strictest sense, nouns with a semantic adjectival status were discarded from the count. However, participles with a semantic adjectival status were included in the count since, as Quirk and Greenbaum (1979) and Bosque (1990) conceded, the difference between adjectives and participles is often not clear-cut and depends on the verbal force retained by the latter. Apart from this, several other problematic issues also arose during the manual selection of evaluative adjectives. As is the case in almost any study in which the author's intuition and subjectivity play an important part, there were dubious instances as regards the accuracy of the label "evaluative" in some adjective types and there were cases in which the "evaluative" feature depended entirely on the context of use. For instance, in our corpus, the adjective "interactive" was found both with an evaluative and non-evaluative dimension:

NON-EVALUATIVE USE: air conditioning, free wi-fi, interactive TV, lovely bathrobes and much more.

EVALUATIVE USE: Philippe Starck's iconoclastic vision has created an exciting and exuberant space, offering a personal and interactive experience that lifts the spirits and stimulates the senses.

In the few cases of this kind that did occur, non-evaluative instances were removed from final evaluative-type counts after a detailed in-context analysis of their real use in the text.

According to English corpus studies on the frequency of the adjectival category authored by Johansson and Hofland (1989) and Hudson (1993), adjectives (in general) constitute approximately $7 \%$ of all word forms. However, as their research also points out, the relation between the frequency of adjectives and text types is fundamental since not every genre favours the use of adjectives in the same way. Our knowledge of the world makes us think that in promotional or interested texts adjectives probably play a more relevant role than in other text types with a less apparent interested nature. With respect to specific genres, studies such as the one by Yamazaki showed that adjectives are used more frequently in informational written texts ( $7.6 \%$ to $8.1 \%$, depending on the corpus), while Biber et al. (1999: $65)$ indicated that news texts constitute one of the highest frequencies of occurrence.

The identification of adjectives (in general) among the 2000 top-frequency types ${ }^{2}$ in the corpus resulted in 290 adjective types. From these 290 preliminarily retrieved "general" adjective types, a subsequent manual selection showed that 130 of them were what we considered to be evaluative adjective types, that is, $45.2 \%$ of the most frequent adjective types in the corpus would be purely evaluative. Regarding tokens, the corpus as a whole had 158928 tokens, whereas the 2000 top-frequency words accounted for 71487 of these tokens. From these 71487 tokens, 3334 corresponded to evaluative adjectives, that is to say, $4.7 \%$ of the tokens from the 2000 top-frequency units in the corpus corresponded to evaluative adjectives. According to these corpus counts, it can thus be stated that evaluative adjectives accounted for approximately half of the adjectives (in general) in the corpus. According to the data provided and as an estimation, it could be stated that adjectives in general would account for some $10 \%$ of all word forms in the corpus, this percentage being higher than the

\footnotetext{
2 "Types" refers to the number of different words appearing in the corpus or in a part of it, whereas "Tokens" refers to the total number of words in the corpus or in a part of it.
} 
above-mentioned value found in previous research on other genres. However, if we stick strictly to the numerical data provided by WST, we must acknowledge that the percentage of evaluative adjectives is high, as expected, with respect to more neutrally-aimed texts. Nevertheless it is still a bit lower than expected, since it was initially hypothesised that in promotional genres, subjective, persuasive language in the form of adjectives would play a more relevant role or would be higher in number than objective, "bare" ones. Additionally, despite this presumed importance of evaluative adjectives in promotional texts, it is interesting to note that the top five adjectives in the corpus were non-evaluative or merely classificatory: available (with a frequency of 431), double (231), free (253), private (216) and standard (203), all of them referring to room management. It is not until position 57 in our corpus that we find an evaluative adjective. This most common evaluative adjective in the corpus is special.

Table $5^{3}$ (first four columns on the left) shows these top-frequency, manually-selected evaluative adjectives from the corpus together with some relevant data as regards their position on the general frequency list or their frequency in the corpus (see section 5.2).

\begin{tabular}{|l|r|l|r|r|r|r|}
\hline & $\begin{array}{c}\text { Place } \\
\text { occupied } \\
\text { in the } \\
\text { general } \\
\text { freq. list }\end{array}$ & $\begin{array}{c}\text { Evaluative } \\
\text { adjectives }\end{array}$ & $\begin{array}{c}\text { Freq. } \\
\text { in the } \\
\text { corpus }\end{array}$ & $\begin{array}{c}\text { ATTRIBUTIVE } \\
\text { POSITION }\end{array}$ & $\begin{array}{c}\text { POSTPOSITIVE } \\
\text { POSITION }\end{array}$ & $\begin{array}{c}\text { PREDICATIVE } \\
\text { POSITION }\end{array}$ \\
\hline 1. & 57 & SPECIAL & $177 / 170$ & 162 & 2 & 6 \\
\hline 2. & 86 & PERFECT & 145 & 100 & 0 & 45 \\
\hline 3. & 90 & COMFORTABLE & 142 & 119 & 3 & 20 \\
\hline 4. & 95 & IDEAL & 138 & 63 & 0 & 75 \\
\hline 5. & 96 & FRIENDLY & 137 & 73 & 42 & 22 \\
\hline 6. & 108 & MODERN & $126 / 125$ & 120 & 0 & 5 \\
\hline 7. & 155 & BEAUTIFUL & 91 & 90 & 0 & 1 \\
\hline 8. & 189 & EASY & 79 & 65 & 2 & 2 \\
\hline 9. & 193 & EXCELLENT & 78 & 76 & 0 & 2 \\
\hline 10. & 252 & LUXURIOUS & 64 & 62 & 0 & 14 \\
\hline 11. & 255 & TRADITIONAL & 64 & 50 & 0 & 30 \\
\hline 12. & 368 & COMMITTED & 47 & 17 & 0 & 4 \\
\hline 13. & 376 & SAFE & $47 / 15$ & 14 & 0 & 2 \\
\hline 14. & 411 & STYLISH & 43 & 39 & 0 & 2 \\
\hline
\end{tabular}

\footnotetext{
3 The grey-coloured part of the table (on the right) corresponds to the syntactic study of evaluative adjectives explained in section 5.2, and has been annexed due to space constraints and to make the content and the corresponding adjective position more visual.

4 Since the frequency we are interested in is that of adjectives, once the contextual analysis has shown the real grammatical category of the lexical units analysed in the corpus, those types initially regarded as evaluative adjectives but having a different grammatical category or non-evaluative nature in our corpus were removed from the final frequency counts provided by WordList. In these cases, two figures were provided: the actual frequency of evaluative adjectives -and thus the one computed-is the lowest figure (accordingly, some of these adjectives should be repositioned in the table).
} 


\begin{tabular}{|c|c|c|c|c|c|c|}
\hline & $\begin{array}{c}\text { Place } \\
\text { occupied } \\
\text { in the } \\
\text { general } \\
\text { freq. list }\end{array}$ & $\begin{array}{l}\text { Evaluative } \\
\text { adjectives }\end{array}$ & $\begin{array}{l}\text { Freq. } \\
\text { in the } \\
\text { corpus }\end{array}$ & $\begin{array}{l}\text { ATTRIBUTIVE } \\
\text { POSITION }\end{array}$ & $\begin{array}{l}\text { POSTPOSITIVE } \\
\text { POSITION }\end{array}$ & $\begin{array}{c}\text { PREDICATIVE } \\
\text { POSITION }\end{array}$ \\
\hline 15. & 435 & NATURAL & 40 & 40 & 0 & 0 \\
\hline 16. & 469 & WONDERFUL & 38 & 38 & 0 & 0 \\
\hline 17. & 470 & COSY & 37 & 33 & 0 & 4 \\
\hline 18 & 484 & ELEGANT & 36 & 33 & 0 & 3 \\
\hline 19. & 488 & FRESH & 36 & 35 & 1 & 0 \\
\hline 20. & 497 & CLASSIC & 35 & 31 & 0 & 4 \\
\hline 21. & 512 & FINE & 34 & 34 & 0 & 0 \\
\hline 22. & 516 & LOWER & 34 & 30 & 0 & 4 \\
\hline 23. & 528 & FAMOUS & 33 & 27 & 1 & 5 \\
\hline 24. & 536 & UNIQUE & 33 & 27 & 0 & 6 \\
\hline 25. & 543 & FANTASTIC & 32 & 32 & 0 & 0 \\
\hline 26. & 559 & WELCOMING & $32 / 26$ & 20 & 0 & 6 \\
\hline 27. & 572 & SECURE & $31 / 27$ & 20 & 0 & 7 \\
\hline 28. & 588 & LOVELY & 30 & 30 & 0 & 0 \\
\hline 29. & 591 & PROFESSIONAL & $30 / 29$ & 27 & 0 & 2 \\
\hline 30. & 593 & REAL & 30 & 30 & 0 & 0 \\
\hline 31. & 600 & PEACEFUL & 29 & 29 & 0 & 0 \\
\hline 32. & 602 & RELAXED & 29 & 26 & 0 & 3 \\
\hline 33. & 609 & CHARMING & 28 & 26 & 0 & 2 \\
\hline 34. & 620 & POPULAR & 28 & 23 & 0 & 5 \\
\hline 35. & 622 & ROMANTIC & 28 & 28 & 0 & 0 \\
\hline 36. & 663 & DELIGHTFUL & 26 & 26 & 0 & 0 \\
\hline 37. & 666 & EXCLUSIVE & 26 & 26 & 0 & 0 \\
\hline 38. & 667 & FABULOUS & 26 & 24 & 0 & 2 \\
\hline 39. & 668 & FINEST & 26 & 24 & 0 & 2 \\
\hline 40. & 673 & ORIGINAL & 26 & 26 & 0 & 0 \\
\hline 41. & 680 & STUNNING & 26 & 26 & 0 & 0 \\
\hline 42. & 681 & SUPERB & 26 & 26 & 0 & 0 \\
\hline 43. & 690 & OUTSTANDING & 25 & 22 & 0 & 3 \\
\hline 44. & 698 & ACTIVE & 24 & 7 & 0 & 17 \\
\hline 45. & 749 & SPECTACULAR & 23 & 22 & 0 & 1 \\
\hline 46. & 770 & HAPPY & 22 & 3 & 0 & 19 \\
\hline 47. & 772 & IMPRESSIVE & 22 & 6 & 0 & 16 \\
\hline 48. & 790 & CONVENIENT & 21 & 13 & 1 & 7 \\
\hline 49. & 792 & DELICIOUS & 21 & 21 & 0 & 0 \\
\hline 50. & 795 & EXCEPTIONAL & 21 & 21 & 0 & 0 \\
\hline 51. & 797 & FLEXIBLE & 21 & 18 & 0 & 3 \\
\hline
\end{tabular}




\begin{tabular}{|c|c|c|c|c|c|c|}
\hline & $\begin{array}{c}\text { Place } \\
\text { occupied } \\
\text { in the } \\
\text { general } \\
\text { freq. list }\end{array}$ & $\begin{array}{l}\text { Evaluative } \\
\text { adjectives }\end{array}$ & $\begin{array}{l}\text { Freq. } \\
\text { in the } \\
\text { corpus }\end{array}$ & $\begin{array}{c}\text { ATTRIBUTIVE } \\
\text { POSITION }\end{array}$ & $\begin{array}{l}\text { POSTPOSITIVE } \\
\text { POSITION }\end{array}$ & $\begin{array}{c}\text { PREDICATIVE } \\
\text { POSITION }\end{array}$ \\
\hline 52. & 801 & INTERACTIVE & $28 / 21$ & 21 & 0 & 0 \\
\hline 53. & 819 & APPROPRIATE & 20 & 16 & 2 & 2 \\
\hline 54. & 825 & BUSY & 20 & 19 & 0 & 1 \\
\hline 55. & 849 & PICTURESQUE & 20 & 20 & 0 & 0 \\
\hline 56. & 853 & RESPONSIBLE & 20 & 8 & 0 & 12 \\
\hline 57. & 856 & SUITABLE & 20 & 7 & 0 & 13 \\
\hline 58. & 857 & SUPER & 20 & 18 & 0 & 2 \\
\hline 59. & 882 & EXCITING & 19 & 16 & 0 & 3 \\
\hline 60. & 893 & MAGNIFICENT & 19 & 19 & 0 & 0 \\
\hline 61 & 896 & MEMORABLE & 19 & 17 & 0 & 2 \\
\hline 62. & 910 & STRONG & 19 & 19 & 0 & 0 \\
\hline 63. & 932 & DESIRABLE & 18 & 16 & 0 & 2 \\
\hline 64. & 994 & ENJOYABLE & 17 & 9 & 0 & 8 \\
\hline 65. & 1042 & FAST & 16 & 10 & 1 & 5 \\
\hline 66. & 1116 & GORGEOUS & 15 & 15 & 0 & 0 \\
\hline 67. & 1120 & INNOVATIVE & 15 & 15 & 0 & 0 \\
\hline 68. & 1144 & ULTIMATE & 15 & 12 & 0 & 3 \\
\hline 69. & 1153 & AMPLE & 14 & 14 & 0 & 0 \\
\hline 70. & 1164 & CHEAP & 14 & 14 & 0 & 0 \\
\hline 71. & 1175 & EFFECTIVE & 14 & 13 & 0 & 1 \\
\hline 72. & 1176 & EFFICIENT & 14 & 14 & 0 & 0 \\
\hline 73. & 1179 & ENTHUSIASTIC & 14 & 3 & 0 & 11 \\
\hline 74. & 1189 & INTIMATE & 14 & 13 & 0 & 1 \\
\hline 75. & 1210 & $\mathrm{RICH}$ & 14 & 13 & 0 & 1 \\
\hline 76. & 1225 & ANTIQUE & 13 & 13 & 0 & 0 \\
\hline 77. & 1254 & EXQUISITE & 13 & 13 & 0 & 0 \\
\hline 78. & 1257 & FORMAL & 13 & 13 & 0 & 0 \\
\hline 79. & 1293 & SOFT & 13 & 13 & 0 & 0 \\
\hline 80. & 1301 & TRANQUIL & 13 & 12 & 0 & 1 \\
\hline 81. & 1312 & ARTISTIC & 12 & 12 & 0 & 0 \\
\hline 82. & 1328 & CORRECT & 12 & 9 & 0 & 3 \\
\hline 83. & 1374 & SMART & 12 & 11 & 0 & 1 \\
\hline 84. & 1380 & STYLED & $12 / 8$ & 8 & 0 & 0 \\
\hline 85. & 1381 & SUCCESSFUL & 12 & 11 & 0 & 1 \\
\hline 86. & 1384 & SWEET & 12 & 12 & 0 & 0 \\
\hline 87. & 1394 & AMAZING & 11 & 11 & 0 & 0 \\
\hline 88. & 1399 & ATTRACTIVE & 11 & 10 & 0 & 1 \\
\hline
\end{tabular}




\begin{tabular}{|c|c|c|c|c|c|c|}
\hline & $\begin{array}{c}\text { Place } \\
\text { occupied } \\
\text { in the } \\
\text { general } \\
\text { freq. list }\end{array}$ & $\begin{array}{l}\text { Evaluative } \\
\text { adjectives }\end{array}$ & $\begin{array}{l}\text { Freq. }{ }^{4} \\
\text { in the } \\
\text { corpus }\end{array}$ & $\begin{array}{l}\text { ATTRIBUTIVE } \\
\text { POSITION }\end{array}$ & $\begin{array}{l}\text { POSTPOSITIVE } \\
\text { POSITION }\end{array}$ & $\begin{array}{l}\text { PREDICATIVE } \\
\text { POSITION }\end{array}$ \\
\hline 89. & 1442 & IDYLLIC & 11 & 10 & 0 & 1 \\
\hline 90. & 1460 & PANORAMIC & 11 & 11 & 0 & 0 \\
\hline 91. & 1465 & PRESTIGIOUS & 11 & 11 & 0 & 0 \\
\hline 92. & 1481 & SMOOTH & 11 & 11 & 0 & 0 \\
\hline 93. & 1502 & ABUNDANT & 10 & 10 & 0 & 0 \\
\hline 94. & 1534 & ENTERTAINING & $10 / 8$ & 2 & 0 & 6 \\
\hline 95. & 1544 & HIDDEN & 10 & 10 & 0 & 0 \\
\hline 96. & 1547 & HUGE & 10 & 10 & 0 & 0 \\
\hline 97. & 1556 & LEGENDARY & 10 & 8 & 0 & 2 \\
\hline 98. & 1565 & POSITIVE & 10 & 10 & 0 & 0 \\
\hline 99. & 1567 & PRACTICAL & 10 & 8 & 0 & 2 \\
\hline 100. & 1574 & REASONABLE & 10 & 10 & 0 & 0 \\
\hline 101. & 1585 & SOPHISTICATED & 10 & 10 & 0 & 0 \\
\hline 102. & 1595 & UNFORGETTABLE & 10 & 10 & 0 & 0 \\
\hline 103. & 1600 & ACCURATE & 9 & 9 & 0 & 0 \\
\hline 104. & 1602 & AFFORDABLE & 9 & 9 & 0 & 0 \\
\hline 105. & 1603 & AIRY & 9 & 9 & 0 & 0 \\
\hline 106. & 1606 & ANCIENT & 9 & 9 & 0 & 0 \\
\hline 107. & 1638 & DELIGHTED & $9 / 8$ & 0 & 0 & 8 \\
\hline 108. & 1649 & DRAMATIC & 9 & 9 & 0 & 0 \\
\hline 109. & 1652 & EASIER & 9 & 6 & 3 & 0 \\
\hline 110. & 1663 & FASHIONABLE & 9 & 9 & 0 & 0 \\
\hline 111. & 1665 & FESTIVE & 9 & 9 & 0 & 0 \\
\hline 112. & 1668 & FREQUENT & 9 & 9 & 0 & 0 \\
\hline 113. & 1678 & HISTORICAL & 9 & 9 & 0 & 0 \\
\hline 114. & 1683 & LEADING & $9 / 6$ & 6 & 0 & 0 \\
\hline 115. & 1700 & POWERFUL & 9 & 9 & 0 & 0 \\
\hline 116. & 1709 & RELEVANT & 9 & 9 & 0 & 0 \\
\hline 117. & 1738 & SUMPTUOUS & 9 & 9 & 0 & 0 \\
\hline 118. & 1739 & SUNNY & 9 & 9 & 0 & 0 \\
\hline 119. & 1750 & VIBRANT & 9 & 9 & 0 & 0 \\
\hline 120. & 1800 & CREATIVE & 8 & 8 & 0 & 0 \\
\hline 121. & 1814 & EXOTIC & 8 & 8 & 0 & 0 \\
\hline 122. & 1817 & FAVOURITE & 8 & 8 & 0 & 0 \\
\hline 123. & 1823 & GLORIOUS & 8 & 8 & 0 & 0 \\
\hline 124. & 1828 & HEARTY & 8 & 8 & 0 & 0 \\
\hline 125. & 1835 & INFORMAL & 8 & 7 & 0 & 1 \\
\hline
\end{tabular}




\begin{tabular}{|c|c|c|c|c|c|c|}
\hline & $\begin{array}{c}\text { Place } \\
\text { occupied } \\
\text { in the } \\
\text { general } \\
\text { freq. list }\end{array}$ & $\begin{array}{l}\text { Evaluative } \\
\text { adjectives }\end{array}$ & $\begin{array}{l}\text { Freq. }{ }^{4} \\
\text { in the } \\
\text { corpus }\end{array}$ & $\begin{array}{l}\text { ATTRIBUTIVE } \\
\text { POSITION }\end{array}$ & $\begin{array}{l}\text { POSTPOSITIVE } \\
\text { POSITION }\end{array}$ & $\begin{array}{c}\text { PREDICATIVE } \\
\text { POSITION }\end{array}$ \\
\hline 126. & 1873 & PROUD & 8 & 0 & 0 & 8 \\
\hline 127. & 1876 & REFRESHING & 8 & 8 & 0 & 0 \\
\hline 128. & 1944 & BRIGHT & 7 & 6 & 0 & 1 \\
\hline 129. & 1979 & CONTINUOUS & 7 & 7 & 0 & 0 \\
\hline 130. & 1999 & DYNAMIC & 7 & 5 & 0 & 2 \\
\hline \multicolumn{3}{|c|}{ TOTAL COUNTS } & $\begin{array}{r}3334 \\
\text { Ev. adj. } \\
\text { tokens }\end{array}$ & $\begin{array}{r}2811 \\
\text { Ev. adj. } \\
\text { tokens }\end{array}$ & $\begin{array}{r}58 \\
\text { Ev. adj. } \\
\text { tokens }\end{array}$ & $\begin{array}{r}465 \\
\text { Ev. adj. } \\
\text { tokens }\end{array}$ \\
\hline
\end{tabular}

Table 5. Evaluative adjectives under analysis: quantitative data from the corpus.

Moreover, as sections 5.3 and 5.4 analyse in more detail but as can already be preliminarily deduced from Table 5, evaluation through adjectives seems to be centred around items such as importance, excellence, beauty, sensory perception, psychological processes and emotions. As expected, all of the evaluative adjectives that were retrieved and analysed constituted positive instances of evaluation. Even for those adjectives that, in a decontextualised analysis like the one provided in Table 5, could seem to constitute dubious instances of positiveness -lower, busy, fast, informal, ...- an in-context analysis showed that in the genre analysed they helped to portray overall positive acts and entities:

\section{Professional night auditors are in charge of the smooth running of our busy check-in} service.

Likewise, we have to look at very low frequency evaluative adjectives to find some (scarce) instances of adjectives with purely negative connotations but, once again, this is only to show that what we are being offered will be just the opposite or will become positive afterwards. This is what happens, for example, with the single instance of bad we find in the corpus:

If the weather turns really bad for you and your family, we can always set up the Karaoke and have a song or two!

Hence, these first (quantitative) results arising from the data analysed up to the moment show that, as expected, promotional or interested genres tend to present rather mundane information as positive or extremely positive, relying heavily for this purpose on adjectives and particularly on evaluative adjectives. However, the most frequent adjectives in the corpus are not evaluative and, as shown in Table 5, from the frequency-of-occurrence perspective, these subjective instances seem to be slightly less significant than other more objective ones.

Nonetheless, the fact that evaluative adjectives do not occupy the top positions as regards frequency may be because evaluative adjectives are far more creative and thus they 
allow for much more variation/creativity than other merely descriptive or classificatory types, such as available or standard, which has a detrimental effect on the total number of evaluative adjective types. As a KWIC analysis of our corpus shows, we can be informed about wonderful, fantastic, fabulous, exceptional, gorgeous or amazing rooms. However, if a room is a standard or a non-smoking room, or if it is available, then it is a standard, non-smoking or available room, and not much creativity is allowed (or necessary).

In conclusion, it may be stated that, together with more subjective appraisals, the potential guest also needs and wants factual, objective, to-the-point information. Moreover, there are certain acts and entities within the hospitality industry that require, as the websites reflect, this objectivity more than others, namely, all the management-related areas.

\subsection{Syntactic distribution of evaluative adjectives in the corpus}

Regarding syntactic aspects, adjectives can be found in three positions: before a noun (attributive position), after a noun (postpositive position) or in the predicate modifying the subject of the sentence via a linking verb or other linking mechanism (predicative position), for instance in "most guests are satisfied". Postpositive adjectives are not as common as predicative and attributive ones; they are normally found in a number of fixed expressions of the "we have plenty of rooms available" type, in which available postmodifies "rooms". Thus, in spite of the predominant (premodifying) attributive position of adjectives, there are two other positions where an adjective can also be placed: after a noun head (thereby postmodifying it, postpositive position) or in the predicate (predicative position). Authors such as Fowler and Kress (1979: 212) found the positioning of adjectives "highly revealing". Quirk et al (1985: 1341) argued that premodifiers (adjectives in attributive position) are the ones "relating to properties which are (relatively) inherent in the head of the noun phrase, visually observable, and objectively recognisable or assessable". In fact, adjectives accompanying nouns to the left tend to be the ones that are the most important and affective for their users, that is, the ones with a higher degree of subjectivity.

According to Quirk et al.'s (1985) views, it must be kept in mind that we are talking about a rather impersonal kind of promotional text in which no specific addresser is identified. It is thus a text in which subjective judgements are obviously present but probably in not such a direct or blatant way as expected, as syntactic analysis also seems to indicate. The focus is not on the hotelier or web designer as such but on the element being promoted. Thus, although a significant number of cases of predicative positioning were found, it is also true that this figure is, once again, a bit lower than we expected.

The observation of Concordance or KWIC lines from our corpus has allowed us to manually note down the number of times each evaluative adjective appeared in each position. Once the corpus counts for determining position were finished, the data were gathered in Table 5 (the three columns in grey on the right) to show the exact figures regarding the position occupied by each of the evaluative adjectives from our corpus. We found that, in spite of the relatively large number of evaluative adjective tokens in predicative position (476), the tendency is clearly towards attributive use (2827 tokens). This quantitative study of the evaluative adjectives in the corpus showed that the discourse used on promotional hotel websites presents $84.1 \%$ of evaluative adjective lemmas/tokens in attributive position, $1.7 \%$ of postpositive ones and $14.2 \%$ of predicatively used evaluative adjectives.

Odisea, $n^{\circ} 12$, ISSN 1578-3820, 2011, 97-123 
With regard to some of the findings we came across, it may be observed, for instance, that the top-frequency adjective special appears 162 times in attributive position, giving rise to concordance lines such as in "as a converted granary, special features include oak beams, arched windows overlooking your own patio". It appears twice in postpositive position, as in: "There can be few things more special than an indulgent romantic evening at The Athenaeum". Finally, it is used six times in predicative position: "every property in our range is special in its own way".

According to the data from our corpus, attributive adjectives have a much higher frequency than predicative or postpositive adjectives in the genre analysed, as is also the general tendency in the English language. However, it was also noticed that adjectives regarded as more prototypically evaluative tend to be much more common in predicative positions, as the 45 predicative instances of perfect, the 20 instance of comfortable or the 75 instances of ideal seem to show, in contrast to other less-prototypically subjective instances such as real (0) or continuous (0). It is thus common in our corpus to find patterns of the "to be perfect for"/ "to be ideal for"/ "to be ideal as" type:

The Langham is perfect for meetings, incentives, conferences and events.

Bluebell's Barn is also ideal as a base for a walking or riding holiday.

Finally, the significant use of concatenated adjectives that enhance the persuasive features of the genre under analysis must also be noted. This double or even triple use of evaluative adjectives - especially in attributive position - highlights the recurrent use of hyperbole in this kind of texts, giving rise to instances such as examples 1 and 2 (below) from the corpus. In the same way, another highly frequent and recurrent rhetorical strategy is to emphasise the evaluation of acts and entities provided by adjectives by means of the use of intensifiers. Intensification (or amplification) has been glossed by Partington (1993) as "a direct indication of a speaker's desire to use and exploit the expression of hyperbole" (p.178) and many examples of this can be found in our corpus (example 3).

(1) Meals are served in our attractive and comfortable dining room.

(2) The Langham London awaits with gorgeous and abundant space.

(3) You can choose between an absolutely fabulous choice of different styles for your luxury serviced apartment.

This syntactic patterning we have just considered is also closely related to the recurrent lexical grouping of units in the discourse under analysis, as illustrated by section 5.3 dealing with collocations.

\subsection{Recurrent lexical patterns in promotional hotel websites: collocational corpus- based analysis}

The term collocation was first introduced by Firth (1957: 14) and was defined as "actual words in habitual company". However, this definition should not be equated with the mere co-occurrence of lexical items but as implying a gradation in collocability among 
the set of words which are found to occur in the environment of a particular lexical item. Accordingly, Halliday (1961) defined collocation as: "the syntagmatic association of lexical items, quantifiable, textually, as the probability that there will occur at $n$ removes (a distance of $n$ lexical items) from an item $x$, the items $a, b, c \ldots$..

As such, not only do collocations provide important evidence for the semantic classification of adjectives, but they also constrain possible output in many cases of lexical and grammatical structuring (Tucker 1998).

Hence, our aim in this section was to compile a list of those syntagmatic items (collocates) that significantly co-occur with a given lexical item (the search word or node) within a specified linear distance $\left(\operatorname{span}^{5}\right)$. We are aware that most of the collocations listed in this section do not constitute denominative units per se, but our purpose here was more concerned with detecting recurrent patterns in promotional hotel websites (to better understand which acts and entities are especially relevant in such websites) than with extracting the monolexical and polylexical terms that normally appear in this discourse. This analysis of recurrent patterns constituted a key step in the development of a classification of evaluative adjectives based on the kind of acts and entities they normally qualify (see section 5.4).

These relevant collocations were revealed and analysed thanks to the Concord applications Collocates and Concordance. The former provides a list of the prospective collocates that appear in the immediate context of the search word (in this case the evaluative adjectives under analysis), arranged according to the frequency with which they appear and showing the frequency with which they occur in each position. The latter provides KWIC lists for a more contextualised analysis. We have, in general, considered to be especially significant all those collocates (forming a collocation) with a joint frequency of appearance of around $10 \%$ with respect to all the instances of the node for those adjectives with a high frequency and any recurrent instance which we considered potentially relevant for lowerfrequency instances.

Accordingly, we observed that it is common to find collocations of evaluative adjectives in the corpus referring to acts and events dealing with aspect, image, appearance and, in general, collocations aimed at appealing to the reader through the aesthetic qualities of the evaluated entities or acts:

LUXURIOUS award-winning spa / experience / retreat / room(s) /

accommodation...

STYLISH environment...

ELEGANT rooms / dining room..

PICTURESQUE views /setting...

SMART restaurant / venues...

ATTRACTIVE surroundings / design...

PANORAMIC views (of/over)

SUMPTUOUS rooms / suite...

BRIGHT room(s) / colour(s)...

\footnotetext{
5 The span used in this study was five words both to the left and to the right of the node, but a wider context was also consulted when necessary.
}

Odisea, $n^{\circ} 12$, ISSN 1578-3820, 2011, 97-123 
The recurrent use of collocations that provide general and always positive overall evaluations of some aspect or feature is also very frequent. These collocations tend to portray overall extraordinariness and as such include many "extreme" evaluative adjectives:

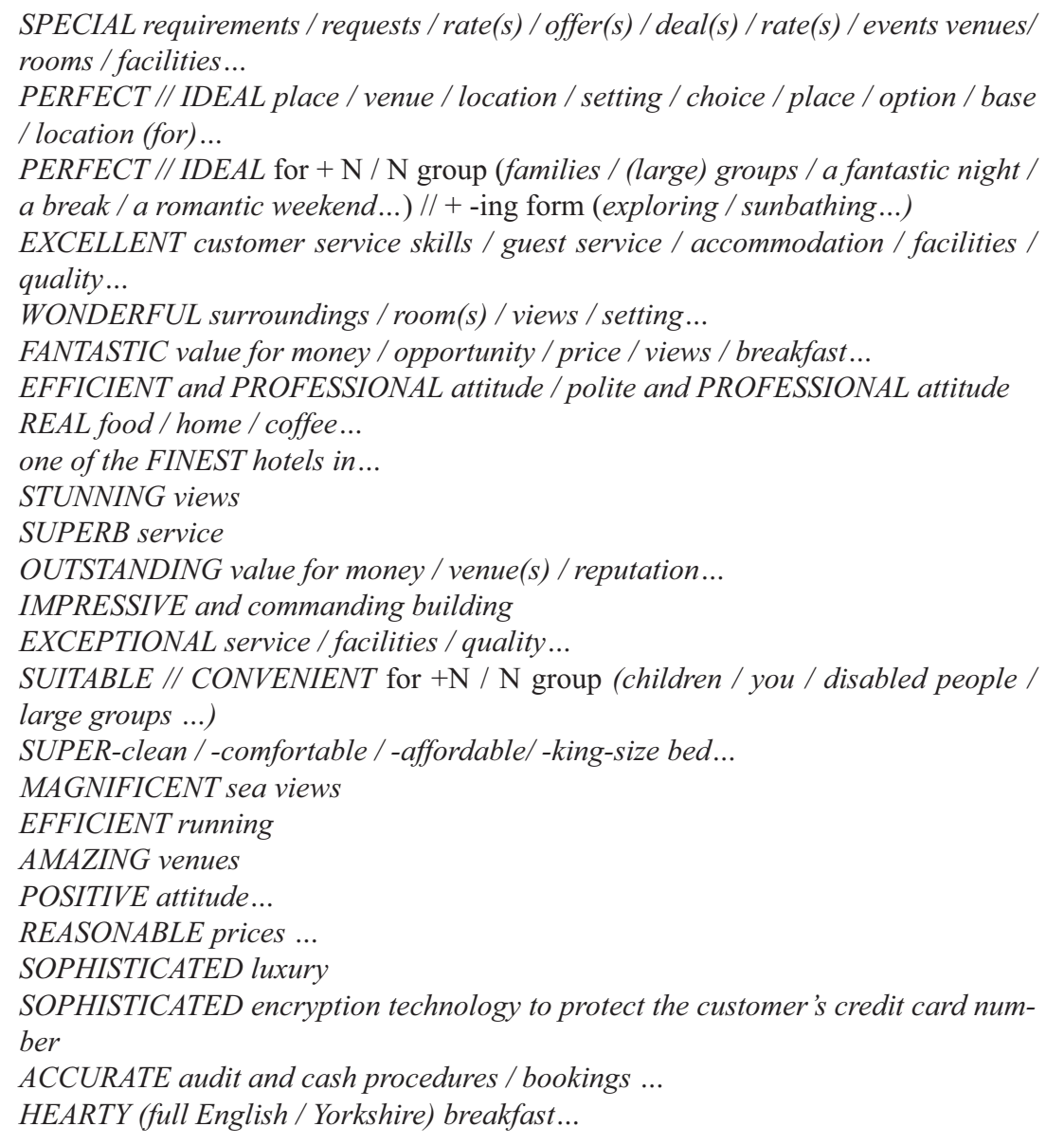

Collocations regarding some sort of special/particular feature or deviation from the average, plain, expected or default values, especially when compared with other similar acts or entities, were also detected:

(Within) EASY access / reach / walking distance.

MODERN technology / rooms / hotel / suite / accommodation / comforts / facilities /

communications facilities and amenities

Equipped with every MODERN amenity

TRADITIONAL English breakfast / dishes...

CLASSIC room / style...

LOWER rate...

Odisea, $n^{\circ} 12$, ISSN 1578-3820, 2011, 97-123 
UNIQUE hotel / design ...

SECURE parking area / booking...

POPULAR destination...

ORIGINAL features...

FAST check(-)in service...

CHEAP hotel rooms...

ANTIQUE furniture...

No HIDDEN extras

AFFORDABLE (hotel) accommodation...

To make life EASIER

FREQUENT services...

INFORMAL atmosphere / surroundings...

Another large category that was identified was that of collocations appealing to guests' feelings, senses, sensations and even emotions:

COMFORTABLE king-size bed / accommodation in the city / room / guest room / double room / accommodation / en-suite accommodation / beds / seating area / hotel / establishment / furnishings...

FRESH towels / flowers /fruit...

WELCOMING atmosphere...

LOVELY bathrobes / garden...

PEACEFUL haven / setting...

RELAXED atmosphere...

ROMANTIC break / occasion...

DELIGHTFUL towelling robe and slippers...

HAPPY to help / cater...

DELICIOUS home cooked meals /coffee...

EXCITING adventure / place...

MEMORABLE stay / experience / 5-star hotel experience

DESIRABLE setting / location...

Look forward to making your stay with us RELAXING and ENJOYABLE

ENTHUSIASTIC in delivering service excellence...

INTIMATE atmosphere...

EXQUISITE taste / studio suites...

SOFT towels...

TRANQUIL stay / area / zone...

SWEET experience...

To be HAPPY // DELIGHTED to assist / welcome / offer...

UNFORGETTABLE occasion / (family/fitness ...) experience...

IDYLLIC surroundings

SMOOTH running (of our busy reception...) / service...

AIRY (open-plan/double/standard...) room

VIBRANT colour $(s) \ldots$

CREATIVE hospitality...

To be PROUD to (say/have/be/include/make...)

REFRESHING selection of (bath products / drinks...)

Odisea, $n^{\circ} 12$, ISSN 1578-3820, 2011, 97-123 
In the case of friendly, it is interesting to note the large number of compounds found in the corpus, probably in an attempt to transmit open-mindedness or some specificity that may be attractive or even necessary for the guest: "child-friendly", "wheelchair-friendly", "family-friendly", "dog-friendly", "disabled-friendly", "walker-friendly", "cyclist-friendly", "gay-friendly", and so on.

Finally, some (but not many) collocations referring to physical qualities stated in an evaluative manner were also found:

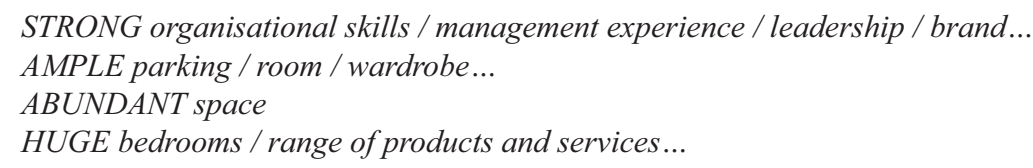

As this analysis of collocations seems to indicate that promotional hotel websites are aimed at attracting customers with a wide variety of needs and tastes, the evaluative principle is thus to accentuate whatever acts and entities can be positive. By so doing it always aims to appear fitting for the particular imagined guest for whom the tourist destination is suitable. These examples of collocations illustrate what Shaw (2006) called the "non-distinctiveness" of the evaluative acts, in which evaluation is not used to discriminate between good and less good cases, but to present just the positive features of the evaluated item.

\subsection{A proposed corpus-based categorisation of evaluative adjectives in promotional hotel websites}

Finally, in order to better understand the use and functioning of evaluative adjectives on promotional hotel websites, we then classified the evaluative adjectives under study (see Table 6). This classification based on functional, semantic and pragmatic criteria is deeply rooted in Swales and Burke's (2003: 5) classification of evaluative adjectives. In their study of these adjectives in academic registers they placed the individual lexical items into one of the following seven categories: acuity, aesthetic appeal, assessment, deviance, relevance, size, and strength. We adapted their classification to match our domain of study and the results obtained so far in an attempt to develop a suitable categorisation that fitted the specificities of this study.

However, as Swales and Burke (2003) themselves recognised, despite our categorisation efforts, we are aware of the fact that both creating the categories themselves and placing individual adjectives within them are somewhat (and once again) subjective processes in which certain reservations will always exist. In the specific case of this study, apart from corpus data itself, intuition and extensive reference to thesauruses and dictionaries played a critical role.

Our categorisation of evaluative adjectives in hotel website discourse resulted in the classification presented in Table 6, where the middle column contains the adjectives from our corpus of study already classified. According to the previous data obtained, this classification was found to have five main categories: aesthetic appeal, general appraisal, deviance, emotional/sensory appeal (not aesthetic) and size/strength-related adjectives. 
From these, aesthetic appeal adjectives would include instances based on visual appeal, appearance, image and beauty. General appraisal adjectives evaluate things more generally from a personal, overall perspective, always insisting on extraordinariness and excellence in a kind of miscellaneous general category that Swales and Burke called "assessment" and which, in our case, would include what they called "relevance adjectives", since we consider them a kind of general appraisal on "extraordinariness". Deviance adjectives, according to Swales and Burke (2003), denote how closely related something is to what one would expect it to be. Emotional/sensory appeal adjectives include adjectives appealing to the reader's emotions and senses, and size/strength-related adjectives are the ones that subjectively qualify acts and entities in terms of intensity and scope.

Hence, in accordance with the results obtained from our corpus so far, the evaluative adjectives under study were classified into the following evaluation-provider types:

\begin{tabular}{|c|c|c|}
\hline $\begin{array}{l}\text { EVALUATION- } \\
\text { P R O V I D E R } \\
\text { TYPES }\end{array}$ & $\begin{array}{l}\text { EVALUATION ADJECTIVES FROM } \\
\text { THE CORPUS OF STUDY }\end{array}$ & $\begin{array}{l}\text { QUANTITATIVE AND } \\
\text { STATISTICAL DATA }\end{array}$ \\
\hline 1. Aesthetic appeal & $\begin{array}{l}\text { Beautiful, luxurious, stylish, elegant, } \\
\text { picturesque, smart, styled, panoramic, } \\
\text { attractive, fashionable, sumptuous, } \\
\text { bright. }\end{array}$ & $\begin{array}{l}12 \text { types; } 321 \text { tokens. } \\
9.2 \% \text { of types in the corpus. } \\
9.6 \% \text { of tokens in the } \\
\text { corpus. }\end{array}$ \\
\hline $\begin{array}{l}\text { 2. General } \\
\text { appraisal }\end{array}$ & $\begin{array}{l}\text { Special,perfect, ideal, excellent,committed, } \\
\text { natural, wonderful, fine, fantastic, } \\
\text { real, fabulous, finest, stunning, superb, } \\
\text { outstanding, spectacular, impressive, } \\
\text { convenient, exceptional, flexible, } \\
\text { appropriate, suitable, super, magnificent, } \\
\text { gorgeous, ultimate, effective, leading, } \\
\text { relevant, efficient, exquisite, correct, } \\
\text { successful, amazing, prestigious, positive, } \\
\text { practical, reasonable, sophisticated, } \\
\text { historical, accurate, dramatic, festive, } \\
\text { glorious, hearty, dynamic, continuous. }\end{array}$ & $\begin{array}{l}47 \text { types; } 1306 \text { tokens. } \\
\begin{array}{l}36.2 \% \text { of types in the } \\
\text { corpus. }\end{array} \\
\begin{array}{l}39.1 \% \text { of tokens in the } \\
\text { corpus. }\end{array}\end{array}$ \\
\hline 3. Deviance & $\begin{array}{l}\text { Modern, easy, traditional, safe, } \\
\text { classic, lower, famous, unique, secure, } \\
\text { professional, popular, exclusive, original, } \\
\text { busy, fast, innovative, cheap, rich, antique, } \\
\text { formal, hidden, affordable, ancient, easier, } \\
\text { frequent, exotic, informal. }\end{array}$ & $\begin{array}{l}27 \text { types; } 721 \text { tokens. } \\
20.8 \% \text { of types in the } \\
\text { corpus. } \\
\begin{array}{l}21.6 \% \text { of tokens in the } \\
\text { corpus. }\end{array}\end{array}$ \\
\hline
\end{tabular}




\begin{tabular}{|l|l|l|}
\hline $\begin{array}{l}\text { EVALUATION- } \\
\text { P R O V I D E R }\end{array}$ & $\begin{array}{l}\text { EVALUATION ADJECTIVES FROM } \\
\text { THE CORPUS OF STUDY }\end{array}$ & $\begin{array}{l}\text { QUANTITATIVE AND } \\
\text { STATISTICAL DATA }\end{array}$ \\
\hline $\begin{array}{l}\text { 4. Emotional/ } \\
\text { sensory appeal } \\
\text { (not aesthetic) }\end{array}$ & $\begin{array}{l}\text { Comfortable, friendly, cosy, fresh, } \\
\text { welcoming, lovely, peaceful, relaxed, } \\
\text { charming, romantic, delightful, active, } \\
\text { happy, delicious, responsible, exciting, } \\
\text { memorable, desirable, enjoyable, soft, } \\
\text { enthusiastic, intimate, tranquil, artistic, } \\
\text { sweet, idyllic, smooth, unforgettable, } \\
\text { entertaining, airy, vibrant, creative, } \\
\text { favourite, proud, refreshing, delighted. }\end{array}$ & $\begin{array}{l}27.8 \% \text { of tokens in } \\
\text { corpus. }\end{array}$ \\
\hline $\begin{array}{l}\text { 5. Size/strength- } \\
\text { related adjectives }\end{array}$ & $\begin{array}{l}\text { Strong, ample, abundant, huge, powerful. } \\
\text { the }\end{array}$ & $\begin{array}{l}3.8 \% \text { of types in the corpus. } \\
1.9 \% \text { of tokens in }\end{array}$ \\
\hline
\end{tabular}

Table 6. Semantic categorisation of evaluative adjectives on promotional hotel websites.

According to our proposed classification and to the quantitative/statistic data obtained (right-hand column), the most frequent sub-category of evaluative adjectives in our corpus would be that of general appraisal. The high frequency of adjectives belonging to this category is probably due to their prototypical evaluative character, whereas size/strengthrelated adjectives (the least frequent ones) probably constitute the class that lies closest to objective, merely descriptive adjectives, and is thus the least prototypical and least frequent one within evaluative types.

The second most frequent class is that of adjectives with an emotional/sensory appeal, in which the subjective perspective and the aim of appealing to the prospective guest's subjectivity is undeniable. Deviance adjectives also display a high frequency, probably in an attempt to show the special character of the advertised entity/act and thus to make them more appealing to the guest. Finally, contrary to what we expected, aesthetic appeal adjectives are not as quantitatively significant as one could think. This is probably due to the fact that hotel promotional websites (like almost any kind of website) rely heavily on the use of images - an image is worth a thousand words - so that evaluation through language is not as necessary as in other aspects, mainly those regarding more abstract concepts.

Thus, we can conclude that purely evaluative adjectives, appealing to customers' subjectivity by denoting general (always) positive judgements or evaluations and psychological/sensory matters are both quantitatively and qualitatively more important than other types of evaluative adjectives on promotional hotel websites. This becomes apparent from the figures showing that they account for two thirds $(66 \%)$ of the evaluative adjectives in the corpus, both from a type and token perspective. 


\section{CONCLUSION}

Our initial hypothesis in this study was that hotel promotion through a website is firmly grounded (especially if compared to other less reader-targeted genres) on a highly significant use of evaluative adjectives, very often in extremely positive and nearly hyperbolic forms, with the aim of persuading and thus turning the reader into a guest.

Promotional hotel websites are expected to contain either a high percentage of or almost exclusively positive or extra-positive (evaluative) adjectives with the aim of portraying the alleged extraordinariness of the product (hotel) being promoted, in which no weaknesses will be reported. However, according to corpus analysis, the subjectivity and judgement features in this discourse - even when crucial and very frequent - are not as numerous as this author expected them to be, since evaluative adjectives do not account for even half of the adjectival types in the corpus.

Evaluative adjectives are ideology markers but, in Shaw's words (2006: 8), "when one reads an interested text one knows that the writer is an advocate for a case, not a judge. Hence, one will not be impressed by pure statements of quality. In fact, the way in which interested texts are read is the key to understanding their evaluation systems". That is probably the key factor explaining the slightly surprising quantitative results obtained in the study: in spite of clearly over-using positive, subjective evaluative statements (as expected) and thus trying to "sell extraordinariness" through discourse, hoteliers are also aware of the fact that too blatant a discourse may not be persuasive at all. Web users are too accustomed to persuasion through hyperbole or to exaggeratedly overt positive judgement and may distrust it, especially when the judge is the persuader. A major conclusion to be drawn could probably be that authors nowadays prefer subtler and less subjective evaluative strategies and the use of evaluative adjectives on hotel websites reflects this tendency towards increasingly unbiased information.

In the same way, it may be concluded that, as corpus results and categorisations showed, some evaluative dimensions are seen to be more central than others in the genre under study and that recurrent, emphatic lexical patterns of an evaluative nature clearly characterise this kind of discourse.

As stated earlier, in the interested, promotional genre that was analysed, the subjective judgements or appraisals portrayed by these adjectives are always positive. An interesting line of further research could thus be, for instance, a comparison of the evaluative adjectives in the promotional hotel websites and in travellers' fora dealing with the same hotels so as to be able to contrast the degree of subjectivity implicit in the judgements and the judgements as such.

Finally, as expected, the use of evaluative adjectives seems to be closely linked to the distribution and organisation of sections on the website and to the communicative purpose and rhetorical function assigned to each of these sections on the site. Thus, evaluative adjectives are especially numerous in hotel presentation and room description sections, where they are used mainly to justify and highlight the excellent qualities of the hotel, and less frequent in the management-related sections.

From this perspective, then, what hoteliers may seem to be aiming at when promoting their hotels through evaluation appears to be to provide (extra-)positive evaluations 
portraying the extraordinariness of the acts and events dealt with. At the same time, they also seek to appeal to the potential guest's emotions and senses by offering an experience with many sensory nuances without forgetting that objective, factual and to-the-point information is also an absolute must on any hotel website.

\section{REFERENCES}

BACHE, C and N. DAvidSEn-Nielsen 1997. Mastering English: An Advanced Grammar for Non-Native and Native Speakers. Berlin/New York: Mouton de Gruyter.

BARton, E. L. 1993 . "Evidentials, argumentation, and epistemological stance". College English, 55 7, 745-771.

Biber, D., Johansson, S., Leech, G., Conrad, S. and E. Finegan 1999 . Longman Grammar of Spoken and Written English. London: Longman.

Bloomfield, L. 1933 . Language. New York/Chicago/San Francisco/Toronto: Holt Rinehart and Winston.

Bosque MuÑoz, I., 1990. Las categorías gramaticales. Madrid: Editorial Síntesis SA.

Fellbaum, C., Gross, D. and K. Miller 1993. "Adjectives in WordNet”. Five Papers on WordNet. Eds. G. Miller et al. CSL Report 43.

Conrad S. and D. BiBer 2000 . Adverbial Marking of Stance in Speech and Writing. Evaluation in Text: Authorial Stance and the Construction of Discourse. Ed. S. Hunston, and G. Thompson, G. Oxford: OUP: 56-73.

Dixon, R. W. 1982. Where have all the adjectives gone? and other essays in syntax and semantics. The Hague: Mouton.

Ferris, C. D. 1993 . The Meaning of Syntax. A Study in the Adjectives of English. London/New York: Longman.

FIRTH, J.R. 1957 . “A synopsis of linguistic theory, 1930-1955”. Studies in Linguistic

Analysis, Special Volume, Philological Society, 1-32.

Fowler, R. and G. KRess 1979 . "Critical linguistics.” Language and Control. Ed.R. Fowler, B. Hodge, G. Kress and T. Trew. London: Routledge and Kegan Paul, 185-214.

FraGaKi, G. 2009 . “A corpus-based categorization of Greek adjectives. Proceedings of the Corpus Linguistics Conference.” CL2009. Obtained from: http://ucrel.lancs. ac.uk/publications/cl2009/

Halliday, M.A.K. 1961. “Categories of the Theory of Grammar”. Word, 17, 241-92.

Hewings, M. 2004. “An ‘important contribution' or 'tiresome reading'? A study of evaluation in peer reviews of journal article submissions". Journal of Applied Linguistics. 1: 247-274. 
Huddleston, R. 1984 . Introduction to the Grammar of English. Cambridge: Cambridge University Press.

Hudson, R. 1993. "Word-classes in performance". Working Papers in Linguistics 5, 45-54.

Hundsnurscher, F. and J. Splett 1982. "Semantik der Adjektive im Deutschen: Analyse der semantischen Relationen". Westdeutscher Verlag.

Hunston, S. and G. Francis 2000 . Pattern Grammar. A Corpus-driven Approach to the Lexical Grammar of English. Amsterdam/Philadelphia: Benjamins.

Hunston, S. and G.Thompson 2000 . Evaluation in Text: Authorial Stance and the Construction of Discourse. Oxford, Oxford University Press.

Halliday, M.A.K. 1985 . An Introduction to Functional Grammar. London: Arnold.

Hyland, K. 2005 . Metadiscourse. London, New York: Continuum.

Kamps, J. and M. MaARTEn 2002. "Visualizing WordNet structure". Proceedings of the 1st International Conference. on Global WordNet, pages 182-186, Mysore, India.

Johansson S. and Hofland K. 1989. Frequency analysis of English vocabulary and grammar. 2 vols. Oxford, Clarendon Press.

Kerbrat-Orecchioni, C. 1980 . L'enonciation. De la subjectivité dans le langage. Paris: Armand Colin

LeE, S. 1994. "Untersuchungen zur Valenz des Adjektivs in der deutschen Gegenwartssprache”. Berlin: Lang.

LeEch, G., 1989. An A-Z of English. Grammar \& usage. London: Nelson.

MaAlej, Z. 1992 . "Interpersonal Perception in Self-promotional discourse". Online version: http://faculty.ksu.edu.sa/zmaalej/Documents/Interpersonal\%20perception. pdf

Majó, J. and N. Galí, 2002. "Internet en la información turística”. IV Congreso "Turismo y Tecnologías de la Información y las Comunicaciones" TuriTec 2002. España. 397-409.

MARTIN J.R. 2000 . "Beyond exchange: APPRAISAL systems in English”. Evaluation in Text. Ed. S. Hunston and G. Thompson. Oxford, Oxford University Press.

Martin, J.R. and P.R.R White 2005 . The Language of Evaluation, Appraisal in English. London and New York: Palgrave Macmillan.

Partington. A. 1993 . 'Corpus evidence of language change: The case of the intensifier'. Technology and text. Eds M. Baker, G. Francis and E. Tognini-Bonelli. Amsterdam: John Benjamins, pp. 177-192.

PiERINI, P. 2009. "Adjectives in tourism English on the web: a corpus-based study". CÍRCULO de Lingüística Aplicada a la Comunicación CLAC . 40/2009, 93-116. Universidad Complutense de Madrid. 
Quirk, R., Greenbaum, S., Leech G. and J. Svartvik 1972 . A Grammar of Contemporary English. London/New York: Longman.

QUiRK, R. and S. GREenBaum 1979. A university grammar of English (9th impression). Longman Group Limited, London.

Quirk, R., Greenbaum, S., Leech, G. and J. Svartvik 1985 . A Comprehensive Grammar of the English Language. London/New York: Longman.

SAmson, C. 2006. “... Is different from...: A corpus-based study of evaluative adjectives in economics discourse". IEEE Transactions on Professional Communication 49 $3,236-45$.

Severin, W. and J. TANKARd Jr. 1992. Communication Theories: Origins, Methods and Uses in the Mass Media. New York, NY: Longman.

SHAw, P. 2006 "Evaluative language in evaluative and promotional genres". Variation in Business and Economics Discourse: Diachronic and Genre Perspectives. Eds. G. Del Lungo, M. Dossena and B. Crawford. Rome: Officina Edizioni

Sinclair, J. 1990 . Collins Cobuild English Grammar. London: Happer Collins.

SOLER, V. 2002. "Analysing adjectives in scientific discourse: an exploratory study with educational applications for Spanish speakers at advanced university level". English for Specific Purposes. Volume 21, Issue 2, 2002, Pages 145-165.

StuBbs, M. 1998. "Language and the Mediation of Experience: Linguistic Representation and Cognitive Orientation." The Handbook of Sociolinguistics. Ed. F. Coulmas. Oxford: Blackwell Publishers, 358-373.

Swales, J. M. and A. BuRKe 2003 . “'It's really fascinating work': Differences in evaluative adjectives across academic registers". Corpus Analysis: Language Structure and Language Use. Eds. P. Leistyna and C. F. Meyer. Amsterdam: Rodopi, $1-18$.

TEYsSIER, J. 1968 . "Notes on the syntax of the adjective in Modern English". Lingua 20, 225-49.

TucKer, G. H. 1997 . "A functional lexicogrammar of adjectives". Functions of Language 42 , 215-50.

--- 1998 . The Lexicogrammar of Adjectives: A Systemic Functional Approach To Lexis. Continuum Publishing Company.

Wong, J. and Law, R. 2005 . "Analysing the intention to purchase on hotel websites: a study of travellers to Hong Kong”. International Journal of Hospitality Management. Volume 24, Issue 3, September 2005, Pages 311-329. 